\title{
Psychological interventions for end-of-life patients and their families
}

\begin{abstract}
Receiving efficient palliative care is the right of every patient and every professional's duty. This assistance should be available to all who need it. However, complying with such determination is still a challenging task in the current health scenario, and it is necessary to make an effort to establish policies aimed at individuals at the end of life and their families. This article presents reflections on the possibilities of psychological interventions for this population, based on a theoretical review. The findings point out that psychologists can assist patients and family members in making their life projects viable, since death does not constitute an obstacle to freedom, but it does give new contours to it. Therefore, it is necessary to understand that dying is not synonymous with death and providing dignity in this final stage of living is one of the possibilities for psychologists and other health professionals to act.
\end{abstract}

Keywords: palliative care, psychology, death, existentialist psychology
Volume 2 Issue 6 - 2018

\author{
Fabíola Langaro,' Daniela Ribeiro Schneider² \\ 'Graduate Program in Psychology, Federal University of Santa \\ Catarina, Brazil \\ ${ }^{2}$ Department of Psychology, Federal University of Santa \\ Catarina, Brazil
}

\begin{abstract}
Correspondence: Fabíola Langaro, Universidade Federal de Santa Catarina, Rua Des. Desembargador Vitor Lima, Caixa postal 476, Sala 214 - Bloco D - CFH, Trindade, Florianópolis SC, CEP 88.040-400, Brazil, Tel +55 483721 - 8607,

Email flamgaro@hotmail.com
\end{abstract}

Received: September 12, 2017 | Published: November 15, 2018

\section{Introduction}

The provision of palliative care in a general sense is implicit when approaching the patient, and it is an important part of the work of health professionals, regardless of their particular training. However, the specialized provision of palliative care to people in advanced stages of severe illnesses with great suffering deserves to be highlighted and prioritized in national health policies. Receiving efficient palliative care is a right of the patient and duty of each professional, and must be available to all who need it. ${ }^{1}$

However, taking care of end-of-life patients can be challenging and complex for teams. Since the beginning of the twenty-first century, it has become common for the death process to be accompanied by high-technology assistance. Thus, approximately half of the patients with chronic diseases who die in hospitals remain hospitalized in Intensive Care Units during their last days of life, being frequently subjected to therapies that "extend situations, not life". In these cases, the death process has five characteristics: it is an extended act; it is a scientific event; it is filled with passivity, since decisions are under the responsibility of professionals, not of the patient; it may become a profane act, since it does not meet the values and beliefs of patients; and finally, it is an isolated and solitary event. ${ }^{2,3}$

The more the disease develops, the greater the need for palliative care. Since the suffering of an individual may present itself in different dimensions (physical, psychological, spiritual, social, and economic), so must the dimensions of care for individuals, especially at the end of their life. ${ }^{4}$ To make it possible, health teams must understand that the social structure where the individual is inserted provides the horizon where they will find the parameters to construct their singularity and which will also shape the particularities of their suffering. ${ }^{5,6}$

\section{Discussion}

In the context of care for end-of-life patients and their families, it is the responsibility of the psychologist working in palliative care teams to offer support for decision-making, expressing feelings and doubts, seeking illness and terminality acceptance, the elaboration of mourning, mediation of critical dialogues, coping with the dying process, assistance to finalize pending matters, and encourage taking patient's and family's beliefs, values and wishes into account for clinical practice ${ }^{7}$ decision-making. Frequently, subjects affected by illness and the imminence of death find it difficult to see choice possibilities, and visualize that there is still life to be lived, a future to be made possible, experiences to be shared. Thus, professionals can offer mediation for patients and their families, allowing them to reflect on their life stories and wishes, by resignifying relationships and situations they lived, helping them to choose actions that enable them to experience their projects of being, once they realize there is still a future to be built, even though it may consist of months, days or even hours.

In addition, it must be remembered that no one becomes a project on their own, since we are social beings par excellence. ${ }^{5}$ Thus, human reality is stitched together by bonds of reciprocity, where each one is the means of the other to carry out their project. ${ }^{6}$ That is, each subject is the co-author of the other's project of being, and therefore, when one's project of being is interrupted by death, the project of other subjects - family, friends, and colleagues - is also affected, altered by such death.

In this sense, any intervention carried out with sick people for whom death is imminent, must include people related to them and to whom their existence and future physical nonexistence will cause significant impact in terms of projects of being, that is, of future. In this care process, those who are dying, if conscious, have the right to be considered as subjects, which means providing as much information as possible, being careful to combine it with psychological support, at the appropriate time, being sensitive to the extent individuals wish to be informed, discussing therapeutic decisions and engaging them in these decisions. ${ }^{8}$

This measure is necessary not only for ethical reasons, but because whenever patients and family members are given the opportunity to actively participate in decision-making processes regarding themselves and/or their loved ones, giving them a chance to engage in open and honest communication, the chances of psychological complications for those involved decrease. Psychological complications are here understood precisely as the unfeasibility of the project and desire of being of the subjects as beings in the world6. For relatives, knowing 
about the proximity of death, saying their goodbyes, making practical/ bureaucratic arrangements (regarding burial, rituals, and legal issues), learning about the patients' wishes and consequently respecting them, as well as making shared decisions among patient, family and team can facilitate the coping process. ${ }^{9}$ In this perspective, for the planning of their intervention, it is important for the psychologist to assess: the emotional state of the family; the relationship they establish with illness, diagnosis and prognosis; family dynamics, including coping strategies, conflicts, interpersonal relationships; and beliefs and values related to death and dying. ${ }^{10}$

In this context, one of the goals of working with end-of-life patients is to help them achieve a sense of acceptance of life and thus acceptance of death. Moreover, helping patients and their families to acknowledge or accept death can be an impetus for transformation, enabling the achievement of goals in the remaining life time. ${ }^{11,12}$ In this work, the objective is to preserve the idea that there is still life to be lived, and there is still time ahead. The paradox of the dynamics at this moment is that the acceptance of death may occur11 through the acceptance of the life that was lived.

\section{Conclusion}

In psychosocial terms, life must be cared for. It is in it and through it that horizons of possibilities and choices, projects feasibility, desires and relationships can be widened, until death effectively removes all possibilities. Considering we are always in relationships, then it is possible to think that the way to death can be shared, since it is not only death that matters, but also the process of dying. Therefore, understanding how illness and death are experienced by subjects, as an "eternal coming into being", is critical for psychology and other areas of health. In addition, psychology, based on its discussion about the subject who falls ill and dies, can support other professionals in their work in health services, since accompanying subjects in their dying process is a challenging event for all those who experience it.

\section{Acknowledgements}

None.

\section{Conflict of interest}

The author declares no conflicts of interest.

\section{References}

1. Maciel MGS, Rodrigues LF, Naylor C, et al. Critérios de qualidade para os cuidados paliativos no Brasil. Documento elaborado pela Academia Nacional de Cuidados Paliativos, Rio de Janeiro. Diagraphic. 2006:1517.

2. Moritz RD. Os profissionais de saúde diante da morte e do morrer. Bioética. 2005;13(2):51-63.

3. Moritz RD, Lago PM, Souza RP, et al.. Terminalidade e cuidados paliativos na unidade de terapia intensiva. Revista Brasileira de Terapia Intensiva. 2008;20(4):422-428.

4. Silva RCF, Hortale VA. Cuidados paliativos oncológicos: elementos para o debate de diretrizes nesta área. Cadernos de Saúde Pública. 2006;22(10):2055-2066.

5. Sartre JP. O existencialismo é um humanismo. Coleção Os Pensadores. São Paulo: Abril Cultural. 1970.

6. Schneider DR. Sartre e a Psicologia Clínica. Florianópolis, Editora da UFSC, Brazil: Springer; 2011:290.

7. Franco MHP. Psicologia. In: Conselho Regional de Medicina do Estado de São Paulo. Cuidado Paliativo. São Paulo: Conselho Regional de Medicina do Estado de São Paulo; 2008:74-76.

8. Incontri D. Equipes interdisciplinares em cuidados paliativos-religando o saber e o sentir. In: Santos FS, editor. Cuidados Paliativos Diretrizes, Humanização e Alívio de Sintomas. 1st ed. São Paulo: Atheneu; 2011:141-148.

9. Langaro F, Hoepfner Junior H, Hatori MTK, et al. Vivência familiar nos cuidados domiciliares em final de vida e processos de luto. RIES. 2015;4(1):153-164.

10. Nunes LV. Papel do psicólogo na equipe de cuidados paliativos. In: Carvalho RT, Parsons HA, editors. Manual de Cuidados Paliativos ANCP. Ampliado e atualizado. 2nd ed. Brazil: Academia Nacional de Cuidados Paliativos; 2012:337-340.

11. Breitbart WS. Retidão, integridade e cuidado: como viver diante da morte. In: Santos FS, editor. Cuidados Paliativos - Diretrizes, Humanização e Alivio de Sintomas. 1st ed. São Paulo: Atheneu. 2011:131-140.

12. Menezes RA. Tomadas de decisão, poder médico e sentimentos no último período de vida. In: Santos FS, editor. Cuidados Paliativos - Diretrizes, Humanização e Alivio de Sintomas. 1st ed. São Paulo: Atheneu. 2011:193-200. 